\title{
The 'fragile' X chromosome in the Martin-Bell- Renpenning syndrome and in males with other forms of familial mental retardation
}

\author{
ROSALYN PROOPS AND TESSA WEBB \\ From the Department of Clinical Genetics, Infant Development Unit, Birmingham Maternity Hospital, \\ Birmingham B15 2TG.
}

SUMMARY A clinical and cytogenetic study has been made of subjects from families who have possible $\mathrm{X}$ linked mental retardation. The families were distinguished as those with a clinical음 diagnosis of Renpenning syndrome and those with other behavioural or physical abnormalities $\vec{P}$ obviating such a diagnosis. All subjects with Renpenning syndrome carried a fragile Xq27-28요 chromosome in more than $4 \%$ of their blood lymphocytes. In addition, two other families who did not have Renpenning syndrome but had similar clinical features also carried the fragile site Xq27-28. A female age effect was observed and one possible carrier of Renpenning syndrome exhibited the $\vec{\oplus}$ fragile $\mathrm{X}$ in $10 \%$ of her lymphocytes but was also mentally retarded. Subjects within the same family $\stackrel{\infty}{.}$ did not always exhibit the fragile site in a comparable proportion of their cells.

$\mathrm{X}$ linked mental retardation is a heterogeneous group of conditions. One of these is the Martin-BellRenpenning syndrome, ${ }^{1-3}$ the clinical features of which have been summarised by Turner et al. ${ }^{4}$ Males with this syndrome are moderately severely retarded (IQ 30 to 60 ), but have no physical, motor, or behavioural abnormalities. They are of normal stature and often have rather long faces and large ears. Some workers have found that in such patients verbal skills are disproportionately lower than cognitive function ${ }^{5}$ resulting in specific developmental dyspraxias in some families. ${ }^{6}$ It has also been reported that enlarged testes, occurring in both pre- and post-pubertal males, are also an associated feature of the Martin-Bell-Renpenning syndrome. ${ }^{78}$

Interest has centred around the confirmation of a specific chromosome abnormality (fragile site at Xq27-28) segregating through some of these families. ${ }^{9-11}$ The fragile site can only be demonstrated in peripheral cells after in vitro manipulation to provide a medium depleted of folic acid, ${ }^{12}$ which possibly results in alteration of other unknown factors. In Australia, this fragile site has been demonstrated in approximately half the $\mathrm{X}$ linked families investigated and has been found in 8 to $50 \%$

Received for publication 15 October 1980 of metaphases examined. Segregation of the $\frac{0}{\mathrm{D}}$ chromosome abnormality through the female $\varrho$ relatives has been demonstrated in some families, $\overrightarrow{\overrightarrow{0}}$ although this is not absolute ${ }^{913}$ and may be dependent on the age at which the females are investigated. Sutherland and Ashforth ${ }^{14}$ and Turner:et $a l^{8}$ have suggested that the group with $\mathrm{X}$ linked mental retardation associated with the fragile site and that associated with macro-orchidism are the 3 same entity, but Jacobs et al ${ }^{15}$ have reported families with macro-orchidism but without the fragile site and vice versa.

This report describes the clinical and cytogenetical investigation of 11 families in the UK.

\section{Methods}

Male patients were included in the study if they weres severely mentally retarded and had at least onew affected male relative who had an identical form of retardation. The type of mental retardation itself waso not an indication or contraindication for inclusion. क्ष Patients were ascertained through asking all con- + sultant psychiatrists at a long term mental handicap hospital (Lea Castle Hospital, Wolverley) for the names of such patients, and by making similan enquiries of community care mental handicapa 
specialists. Five index patients were ascertained through the hospital and three through community specialists. One family (family W) came to our attention because the sister was referred for genetic counselling.

The study was given impetus by the referral of an isolated retarded male ( $\mathrm{CHa}$ ) who had already been found to carry a fragile $\mathrm{X}$ chromosome. He was first investigated in 1969 when $40 \%$ of his cells carried a fragile site on Xq. A repeat investigation made in 1973 using Ham's F10 medium failed to demonstrate the abnormality. As he had severe behavioural problems he was not considered to have Renpenning syndrome. A second isolated boy (DTe) was referred with a clinical diagnosis of Renpenning syndrome.

Although neither of these boys had any affected relatives and so they do not strictly come within the scope of the study, their clinical symptoms and signs are included in table 1 and the chromosome analyses in table $\mathbf{2}$ for the sake of comparison with the other cases.
TABLE 2 Chromosome analysis in subjects with mental retardation and a possible $X$ linked pedigree

\begin{tabular}{|c|c|c|c|c|c|}
\hline \multirow{2}{*}{$\begin{array}{l}\text { Family } \\
\text { and } \\
\text { subject }\end{array}$} & \multicolumn{3}{|c|}{ Medium $199+2 \%$ serum } & \multicolumn{2}{|c|}{ Medium RPMI $+10 \%$ serum } \\
\hline & $\begin{array}{l}\text { No of cells } \\
\text { studied }\end{array}$ & $\begin{array}{l}\text { No of cells } \\
\text { with fragile } X\end{array}$ & $\%$ & $\begin{array}{l}\text { No of cells } \\
\text { studied }\end{array}$ & $\begin{array}{l}\text { No of cells } \\
\text { with fragile } X\end{array}$ \\
\hline JW & 50 & 8 & 16 & 50 & - \\
\hline TW & 50 & 13 & 26 & 50 & - \\
\hline AlH & 100 & 4 & 4 & & \\
\hline VH & 50 & 16 & 32 & 50 & - \\
\hline $\mathbf{A H}$ & 50 & 14 & 28 & 50 & - \\
\hline DTe & 50 & 13 & 26 & 50 & - \\
\hline DBa & 130 & 3 & 2 & & \\
\hline DD & 50 & - & & & \\
\hline KD & 50 & - & & & \\
\hline DF & 60 & 6 & 10 & 50 & - \\
\hline JF & 70 & 4 & 6 & 50 & - \\
\hline EL & 60 & 1 & 2 & & \\
\hline $\mathbf{R L}$ & 60 & 2 & 3 & & \\
\hline JT & 70 & 2 & 3 & & \\
\hline DT & 50 & - & & & \\
\hline CB & 60 & 2 & 3 & & \\
\hline $\mathrm{MHe}$ & 50 & - & & & \\
\hline $\mathrm{CHa}$ & 50 & 24 & 48 & 50 & - \\
\hline
\end{tabular}

TABLE 1 Clinical assessment of nine families with pedigrees compatible with $X$ linked mental retardation

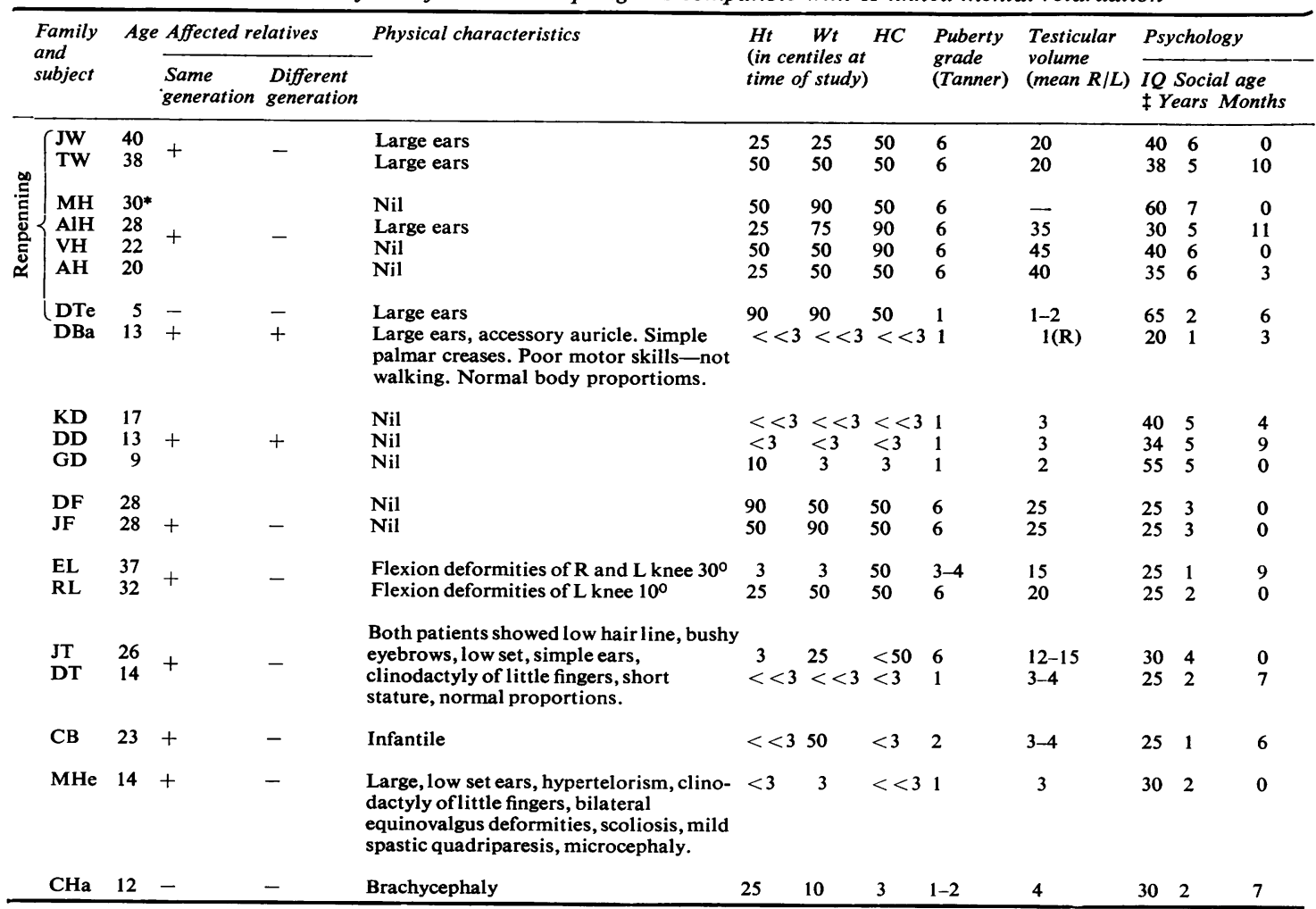

*Female

†Mean of Peabody and Leiter scale 
All the retarded males were clinically examined fully, including a neurological assessment. Height, weight, and head circumference were measured, pubertal stage determined on the Tanner scale, ${ }^{16}$ and testicular volume estimated using a standard orchidometer. ${ }^{17} 18$ Psychological assessment was made of each subject using the Vineland social maturity scale and a Peabody picture vocabulary test to assess comprehensive verbal ability. Cognitive function was determined on the Leiter international performance scale. Finally, the index patient's family was visited to obtain a pedigree and to study any affected relatives.

\section{Cytogenetics}

Peripheral blood samples were cultured in the presence of phytohaemagglutinin (PHA) both in medium RPMI 1640 with $10 \%$ fetal calf serum (FCS) and also in medium 199 supplemented with only $2 \%$ FCS. The latter conditions result in a deficiency of both thymidine and folic acid. ${ }^{12}$ After 72 hours, chromosome preparations were made by standard methods and the slides stained overnight in $2 \%$ orcein. The cells cultured in medium 199 were examined for the presence of a fragile $\mathrm{X}$ chromosome. At least 50 cells were examined from each subject and, although not all were fully analysed, each was counted to ensure that every chromosome was observed. Broken cells were not included in order to eliminate the possibility of false negatives.

A cell was considered to carry a fragile $X$ if it contained a chromosome such as those illustrated in fig 1 . The fragile chromosome from each subject considered to carry the fragile site was confirmed as an $\mathrm{X}$ by Giemsa banding. ${ }^{19}$ In addition, the chromosome preparation obtained with RPMI medium and $10 \%$ FCS was also studied for these subjects to ensure that the fragile $X$ was genuinely induced by the culture conditions and was not a constitutional abnormality.

Observations were made on nine index patients, seven secondary cases, and six female relatives. In addition, studies were made on chromosomes from five normal males, from two mentally retarded males who had similarly affected sisters, from the isolated male with a clinical diagnosis of Renpenning syndrome, and from the isolated male with a fragile site on Xq, and both of their mothers. Scoring of the fragile site was 'blind' in that the type of mental retardation was not discussed before the cytogenetic investigation of the patient, except in the case of DTe where a clinical diagnosis of Renpenning syndrome in an isolated male was referred for cytogenetic confirmation.

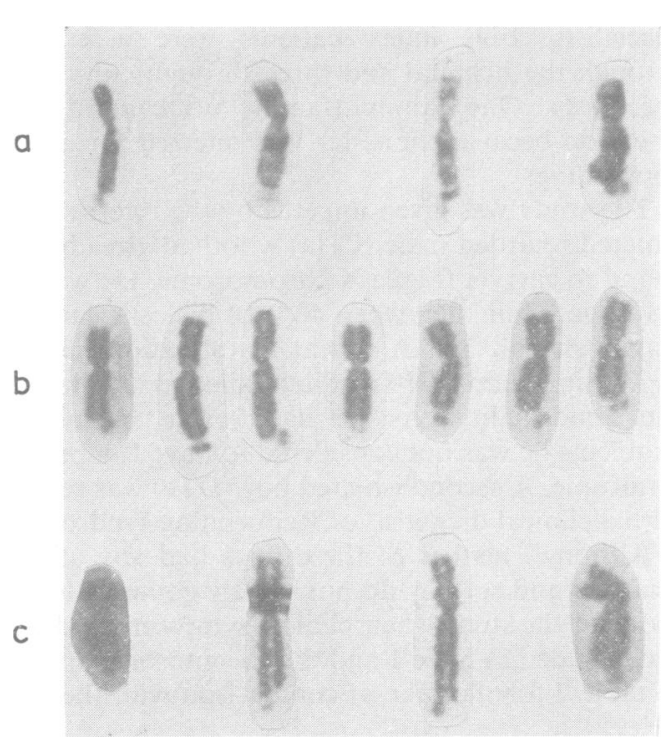

FIG 1 Examples of the fragile site Xq27-28. a. Giemsa banding. $b$. Orcein staining showing the 'satellited' effect at Xq27-28. c. Orcein stained examples where one 'satellite' may be missing.

\section{Results}

PATIENTS WITH MARTIN-BELL-RENPENNING SYNDROME

The index patients were categorised according tō whether or not they had the clinical features of the Martin-Bell-Renpenning syndrome (fig 2). ${ }^{1-3}$ There were two males who fitted this clinical picture. In their families four out of five brothers were similarlys affected and none of the parents was consanguineous? In one family there were affected male relatives outside the index patients' sibship in a distribution compatible with $X$ linkage (figi3).

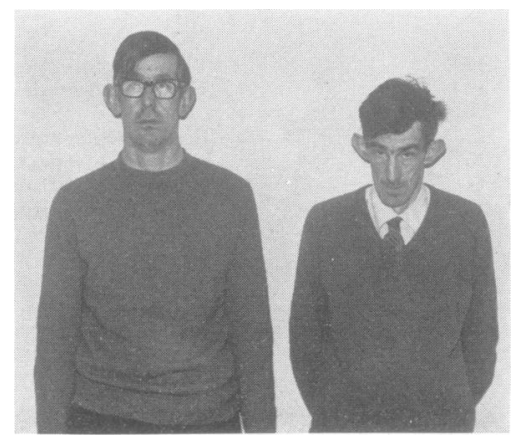

FIG 2 Brothers JW and TW showing normal facial appearance but large 'bat' ears. 
I

III

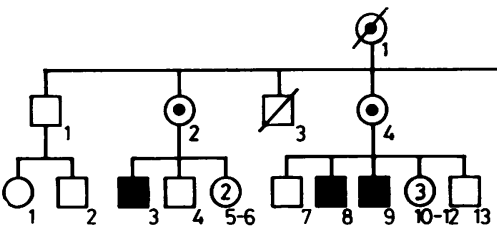

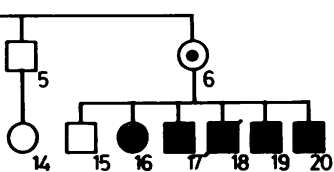

FIG 3 Pedigree of family H. I.I born 1885, died 1943. II.6 born 1927. III.3 born 1946. Retarded. Attends adult training centre. III.8,9 Retarded. No details available. III.15 born 1948. III.16 MH born 1950. Retarded. III.17 AlH born 1952. Retarded. III.18 born 1954. Died 18 months of bronchopneumonia. Retarded. III.19 VH born 1958. Retarded. III.20 AH born 1960. Retarded.

The clinical, family, and cytogenetic findings of these two index patients and three of the secondary cases are given in more detail below.

\section{Family $W$}

The two boys were born when their mother was in her twenties. Pregnancy and delivery were entirely normal with birthweights of approximately $3 \mathrm{~kg}$. The family first became concerned with their development when the boys were 2 years old but they were able to attend normal school until the age of 5 to 6 years. Now aged $\mathbf{4 0}$ years and 38 years, they live in a hostel and attend a sheltered workshop. They are quiet and helpful and cope well with sheltered life.

They are of normal stature and appearance, although both have large 'bat' ears (fig 2). They have normal adult genitalia with a mean testicular volume of $20 \mathrm{ml}$, which is equal to the 90th centile. Chromosome analysis demonstrated $16 \%$ and $26 \%$, respectively, of cells with the fragile $\mathrm{X}$. Their mother has died, but a sister aged 32 years has a normal karyotype (table 3 ). There are no other known cases of mental retardation in the family.

Family $H$ (fig 3)

A boy (III.17) was born weighing $3.4 \mathrm{~kg}$ after a normal pregnancy and delivery. He walked at 18

TABLE 3 Chromosome analysis in female relatives of subjects with mental retardation and possible $X$ linked pedigree.

\begin{tabular}{llllr}
\hline $\begin{array}{l}\text { Family } \\
\text { and subject }\end{array}$ & Age & \multicolumn{4}{l}{ Medium 199+2\% serum } \\
\cline { 2 - 5 } & & $\begin{array}{l}\text { No of cells } \\
\text { studied }\end{array}$ & $\begin{array}{l}\text { No of cells } \\
\text { with fragile X }\end{array}$ & $\%$ \\
\hline Mrs Li* $^{*}$ & 32 & 50 & - & \\
MH & 30 & 50 & 5 & 10 \\
Mrs H (mother) & 53 & 50 & 1 & 2 \\
Mrs D (mother) & 39 & 50 & - & 6 \\
Mrs F (mother) & 63 & 50 & 3 & \\
Mrs L (mother) & 76 & 50 & - & \\
Mrs Ha (mother) & 48 & 50 & - & \\
Mrs Te (mother) & 37 & 50 & - & \\
\hline
\end{tabular}

*Sister to subjects JW and TW months and said single words by 2 years, but was recognised by his family to be retarded by 3 years of age. He was able to attend normal school until he was 6 years old. He is now 28 years old and lives permanently in hospital. He has neither motor nor behavioural problems and is able to attend the hospital workshops. He is of normal stature and appearance but has large ears and pronounced macro-orchidism with a mean testicular volume of $35 \mathrm{ml}$.

Two younger male sibs are similarly affected but are able to attend a local day centre and live at home. Both have enlarged testes, their mean testicular volume being 45 and $40 \mathrm{ml}$, respectively. A fourth retarded boy died at 2 years of age from bronchopneumonia. Their sister (III.16) is also retarded with an IQ of 60 but she has severe behavioural problems. The mental handicap specialist has commented that her behaviour and demeanour are markedly different from that of her male sibs.

Chromosome analysis in the proband has demonstrated $4 \%$ of cells with the fragile $X$ and $28 \%$ and $32 \%$, respectively, in his two brothers. His sister (MH) showed $10 \%$ of cells with a fragile $X$ at 30 years of age, whereas his mother's chromosomes at age 53 years were found to be normal.

\section{Isolated case DTe}

In this boy, motor delay was recognised by 18 months and a marked speech delay recognised by $2 \frac{1}{2}$ years. Now aged 5 years, he has no behavioural problems and attends special school. He is of normal stature but has large ears. There are no other cases of mental retardation in the family.

\section{PATIENTS WITH OTHER FORMS OF FAMILIAL MENTAL RETARDATION}

In contrast to the above families, there were seven index patients who had one or more associated abnormalities which made the diagnosis of the Martin-Bell-Renpenning syndrome in them untenable. Two families (figs 4,5 ) had affected male relatives outside the index patient sibship in a pattern consistent with $\mathrm{X}$ linkage. The clinical, family, and cytogenetic information on the seven 


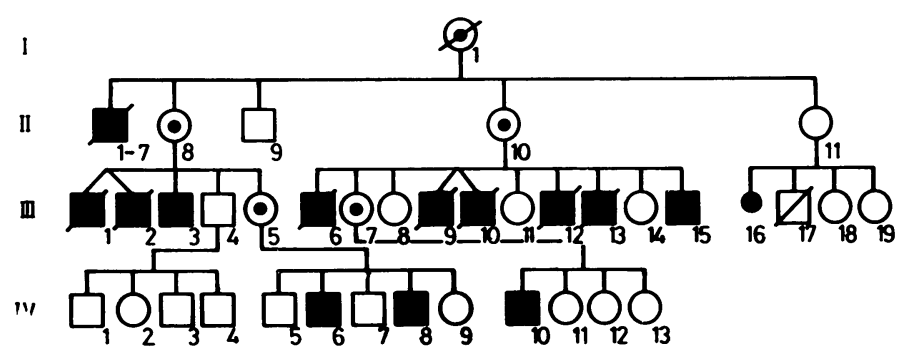

FIG 4 Pedigree of family Ba. I.1 born 1905, died 1960. II.1-7 died aged 3 months-3 years. Described as retarded. No details available. II.8 born 1925. II.10 born 1928. Normal intelligence. III.1,2 born 1938. Died in infancy. Retarded. III.3 born 1940. Retarded. III.5 born 1950. III.6 born 1948. Died aged 6 months of bronchopneumonia. Retarded. III.7 born 1949. III. 8 born 1950. III.9,10 born 1953. Died aged 12 months, 15 months of bronchopneumonia. $\vec{\infty}$ Retarded. III.11 born 1955. III.12 born 1957. Died aged 12 years. Accidental strangulation while in hospital. Retarded. 0 III.13 born 1962. Died aged 10 months of gastroenteritis. Retarded. III.14 born 1965. III.15 born 1969. Proband (DBa). ஸे IV.6 born 1970. Retarded. IV.8 born 1974. Retarded. IV.10 born 1968. Retarded. IV.11 born 1968. IV.12,13 born 1974, ه 1976. Amniocentesis for sex determination.

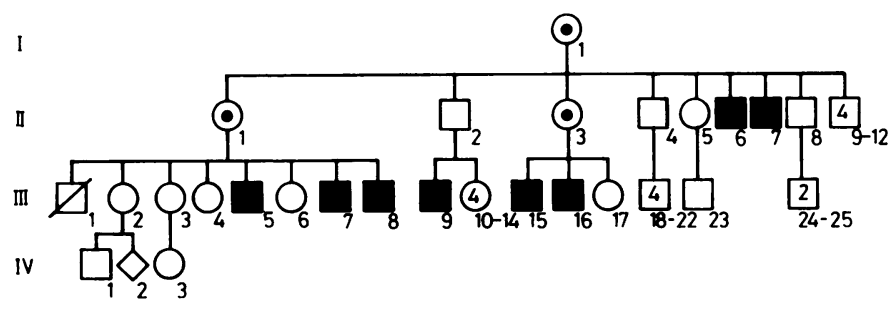

FIG 5 Pedigree of family D. I.1 born 1921. II.1 born 1941. II.6,7 born 1951, 1953. Retarded. Attend adult training centres. III. $1 \stackrel{\Phi}{\Phi}$ born 1958. Died aged 5 days of pneumonia. III.2 born 1959. III.3 born 1961. III.4 born $œ$ 1962. III.5 born 1963. Retarded (KD). III.6. ${ }^{-}$ born 1964. III.7 born 1967. Retarded (DD). 뭉 III.8 born 1971. Retarded (GD). III.9 born 1974. Mildly retarded. Investigations negative. III.15,16 born 1972, 1974. Retarded. Attend $\operatorname{ESN}(S)$ schools. index patients and on four secondary cases who were investigated are detailed below.

\section{Family Ba (fig 4)}

This boy (III.15) was born weighing $3 \cdot 2 \mathrm{~kg}$ after a normal pregnancy. It was his mother's ninth pregnancy at 39 years of age. He was difficult to feed and gained weight slowly. By 18 months, it was apparent that he was retarded and at 3 years he could sit without support and drink from a cup. He has made little progress and now aged 13 years is severely retarded living permanently in hospital. He is able to walk if assisted but has no independent skills. He plays with toys in a purposeless manner and relates to a few familiar adults. $\mathrm{He}$ has behavioural problems with temper tantrums and self destructive behaviour, which manifests as continually picking and scratching himself if not restrained. He has no speech, but makes 'happy and sad' noises. He has frequent respiratory tract and skin infections but no underlying abnormality has been found.

At 13 years, his height is equivalent to that of an 8 -year-old, with normal proportions (head circum- ference, weight, span) but coarse facies. He is prepubertal with genitalia at Tanner stage I and an undescended left testis. The right testis is of normal size for his development $(1 \mathrm{ml})$. Despite the pedigree 3 (fig 4), neither his behavioural nor his physical: characteristics are compatible with a diagnosis of 3 . Renpenning syndrome.

His five brothers were similarly affected and all died by 15 years of age from infections or accidents. 0 Severe mental retardation associated with an unusual propensity to acquire fatal infections has been? confirmed through four generations in this family.

Chromosome analysis has demonstrated $2 \%$ of $\tilde{N}$ cells with a fragile site.

\section{Family $D($ fig 5$)$}

This family presented with three boys aged 17,13, and 9 years. Their birthweights were $2 \cdot 8$ to $3 \cdot 2 \mathrm{~kg}$ ? and they had no neonatal problems. The eldest, whoo was born when their mother was 23 years old, had ${ }_{7}^{+}$ severe pneumonia at one year. By 18 months it waso apparent that he was retarded, he sat unsupported at $\vec{\Phi}$ 14 months, walked at 3 years, and his speech and $\frac{P}{\mathbb{O}}$ social responses were delayed. The younger boys $\frac{\circ}{\sigma}$ 
progressed normally until 2 years but at 4 years they also were assessed as mentally retarded. All three attend special school; they are placid children and have no behavioural or motor problems. They are of normal appearance with no neurological abnormalities, but the two older boys are below the 3rd centile for height, weight, and head circumference and the eldest boy had delayed puberty. These physical characteristics preclude a clinical diagnosis of Renpenning syndrome.

The family history is compatible with $\mathrm{X}$ linked inheritance of mental retardation with seven retarded males in two generations. III.9, aged 6 years, is of normal stature and mildly retarded.

Chromosome analysis of the two elder boys and their mother was entirely normal with no evidence of the marker $\mathrm{X}$ chromosome. The youngest boy was unwilling to donate a blood sample.

\section{Other families}

In the remaining five families in this group, clinical and cytogenetic information is listed in table 1 . The affected male relatives in these families were all brothers. The subjects from family $F$ were monozygotic twins who were autistic with severe behavioural problems and occasional generalised convulsions. They also had enlarged testes measuring $25 \mathrm{ml}$, which is greater than the 90th centile. Family L presented with two retarded males again with severe behavioural problems but also with flexion deformities of the knees. In family $T$ the two retarded males had short stature, unusual facial appearance, and occasional generalised convulsions. The proband from family B was severely retarded with short stature and hyperactive behaviour. His three retarded male sibs were not examined. Family He presented as a retarded male with microcephaly, unusual facies, and mild spastic quadriparesis. His similarly affected younger brother was not examined. Apart from the twins in family $F$ who had enlarged testes, the affected males in this group of families had testicular volumes in keeping with their pubertal grade.

Chromosome analysis for the five index patients and for the three secondary cases in this group, after incubation of lymphocytes in 199 medium with $2 \%$ FCS, demonstrated 0 to $10 \%$ of cells with a fragile $X$ (table 2). The mother from family $F$, whose sons showed 6 and $10 \%$ respectively of cells with the fragile $\mathrm{X}$, had $6 \%$ of such cells herself at the age of 63 .

\section{Discussion}

We agree that the fragile site on $\mathrm{Xq}$ is a real phenomenon and is dependent upon the constituents of the culture medium, as we were unable to demonstrate it in RPMI 1640 with $10 \%$ FCS (table 2). The metabolic cause of the abnormality remains unexplained. The patients investigated all have 'normal' balanced diets and there is no reason to implicate in vivo vitamin deficiencies. Earlier work with in vivo folic acid and/or vitamin $\mathrm{B}_{12}$ deficient patients showed a similar chromosomal abnormality. ${ }^{20}$

In the subjects investigated, several types of abnormality could sometimes be seen within the same patient, including chromatid and chromosome breaks and most commonly the 'satellite' effect (fig 1). ${ }^{10}$

Renpenning syndrome is a defined disorder which includes severely retarded males of normal appearance and normal stature. A striking clinical similarity within this group is their behaviour; they are quiet and 'well behaved', without the maladjusted traits seen frequently in the severely retarded population. These boys usually cope well with sheltered life in spite of their low level of abilities. Two families ( $\mathrm{W}$ and $\mathrm{H}$ ) and one isolated case were considered to have this condition.

Turner et $a l^{7} 8$ described several families with non-specific $\mathrm{X}$ linked mental retardation (clinically Renpenning syndrome) where the affected males had testicular enlargement. This appears to be an unexplained finding as histology and endocrine function are within normal limits. Testicular volume correlates with pubertal stage, but less consistently with chronological age. Once adolescence is completed, testicular size remains constant, certainly until 70 years of age. ${ }^{21}$

Although several authors have reported that $\mathrm{X}$ linked mental retardation with macro-orchidism is the same entity as $X$ linked mental retardation with a fragile $\mathrm{X}$ at q27 or q28, ${ }^{14}$ this finding has not always been confirmed, ${ }^{15}$ and it is possible that more than one clinical entity is being described. In the present study all the adult males with Renpenning syndrome had large testes but so did the twins from family $F$.

It has also been suggested ${ }^{56}$ that verbal disability may correlate with non-specific $X$ linked mental retardation, although this has also been questioned..$^{22}$ Despite the wide range of clinical findings which accompany $X$ linked mental retardation, there has hitherto been no attempt to correlate these with the presence or absence of the fragile $\mathrm{X}$, macroorchidism, or verbal disability. Retarded males with pedigrees compatible with the presence of $\mathrm{X}$ linked mental retardation have been assessed not only for the presence of the fragile $\mathrm{X}$, for macro-orchidism, and for verbal disability, but also for further physical or motor disabilities or both. Because of the severe 
degree of retardation and the wide age range, it was difficult to make valid comments on psychological ability or to make intragroup comparisons of verbal versus cognitive function.

Two families ( $W$ and $H$ ) were considered on clinical evidence to have Renpenning syndrome. The adults all had macro-orchidism ( $\geq 90$ th centile) and all the retarded subjects had the fragile $X$. The isolated male with a clinical diagnosis of Renpenning syndrome also carried the fragile site on Xq. At 5 years of age he has not been reported as having macro-orchidism, but his verbal skills are considerably below his motor ability.

The twins from family $\mathrm{F}$ share features in common with subject $\mathrm{CHa}$. They have severe behavioural problems, being described as autistic, but are of normal stature and appearance. The twins have macro-orchidism but $\mathrm{CHa}$, who is prepubertal, has normal genitalia. All three subjects had a significant number of cultured cells with the fragile $X$, the twins having $10 \%$ and $6 \%$ respectively, while $\mathrm{CHa}$ had $48 \%$.

Families $\mathrm{Ba}$ and $\mathrm{D}$ contain subjects who clinically and by pedigree have $X$ linked mental retardation, but as they have associated behavioural or physical abnormalities or both cannot be considered as Renpenning syndrome. None of the retarded boys from these families had the fragile site at $\mathrm{Xq}$ in more than $2 \%$ of the cells and testicular size was in keeping with pubertal grade. It is suggested that both of these families have distinct and separate forms of $X$ linked mental retardation.

The remaining four families $(\mathrm{L}, \mathrm{T}, \mathrm{B}$, and $\mathrm{He}$ ) probably represent examples of Penrose's 'private family syndromes' ${ }^{23}$ None of the boys in this group had either macro-orchidism or the fragile $\mathbf{X}$ in more than $3 \%$ of cells examined, and the families all contained subjects with retarded growth characteristics and abnormal behaviour.

The presence of the 'fragile' $X$ is not consistent throughout the same family. The proband in family $\mathrm{H}$ had only $4 \%$ of cells affected, while his two younger brothers had $28 \%$ and $32 \%$, respectively (table 2 ). Non-correlation between affected family members for the presence of the fragile $\mathrm{X}$ is difficult to understand as the three affected brothers must have inherited the same fragile site from their mother (although at different times) and culture conditions were identical in all three cases. It is possible that crossovers occurring during meiosis, which may result in the brothers having non-identical $X$ chromosomes, may affect expression in different subjects, although this would further identify the mental retardation gene with the fragile site itself.

Family $\mathbf{H}$ is further complicated by the presence of a retarded sister, although she has clinically dissimilar symptoms. Her chromosomes are normal, except that she shows the fragile site in $10 \%$ of the cells cultured in 199 and $2 \%$ FCS, indicating that she may be a carrier of the disease. The presence of this sister accompanied by the finding that only $4 \%$ of cells from the proband carried a fragile $X$ almost caused the family to be misdiagnosed and illustrates that every retarded male in such a family must be examined. The maternal fragile $X$ is extremely difficult to demonstrate and is known to be complicated by an age effect. ${ }^{13}$ The girl in this study who demonstrated the fragile $X$ chromosome in a significant proportion of her cells $(10 \%)$ was also mentally retarded and, at $\mathbf{3 0}$ years of age, was also the youngest female investigated. All the likely carrier females were over the age of 35 years and only one demonstrated the fragile $X$ in more than $4 \%$ of her cells. More younger obligate carriers should be sought and studied carefully. The age effect does not operate in males who manifest the fragile $X$, as subject $\mathrm{Ha}$ had $40 \%$ of his cells demonstrating it in 1969 and $48 \%$ in 1980 .

From our data, we consider that the percentage of chromosomes with the abnormality is decisive in categorising the condition as $\mathrm{X}$ linked mental retardation. Levels of 2 to $3 \%$ have been demonstrated in several of our subjects, including one normal 23-year-old male control (tables 2 and 4). Although present in only one cell, the abnormality was indistinguishable from that present in the families described above, and we suggest that differences in degree must be instrumental in the determination of clinical disease. Further studies should be made on the levels within families, as this study has revealed one in which clinically similar brothers had widely differing numbers of fragile $\mathrm{X}$ sites in their lymphocytes.

In order to assess the reproducibility and accuracy of our findings, further blood samples were obtained from four of the patients and the cytogenetics were repeated. Subjects DBa and DT were once again

TABLE 4 Chromosome analysis in male controls.

\begin{tabular}{|c|c|c|c|c|c|}
\hline \multirow[t]{2}{*}{ Subject } & \multirow[t]{2}{*}{ Diagnosis } & \multirow[t]{2}{*}{ Age } & \multicolumn{3}{|c|}{ Medium $199+2 \%$ serum } \\
\hline & & & $\begin{array}{l}\text { No of cells } \\
\text { examined }\end{array}$ & $\begin{array}{l}\text { No of cells } \\
\text { with fragile } X\end{array}$ & $\%$ \\
\hline PA & MR & 6 & 50 & - & \\
\hline JJ & MR & 18 & 50 & - & \\
\hline GDu & Normal & 36 & 50 & 一 & \\
\hline $\mathbf{R W r}$ & Normal & 53 & 50 & - & \\
\hline FWe & Normal & 15 & 50 & - & \\
\hline $\mathrm{SFe}$ & Normal & 23 & 50 & 1 & 2 \\
\hline Mr F & Father of family $F$ & 65 & 50 & - & \\
\hline
\end{tabular}

MR, mental retardation 
found not to carry a fragile site and $\mathrm{CHa}$ had the fragile $X$, again confirmed by banding, in a very high proportion $(24 / 50)$ of his cells. The only subject whose second sample was at all at variance with his first was $\mathrm{AlH}$ where the number of cells carrying a fragile site at Xq27-28 rose from $4 \%$ to $10 \%$. The fragile chromosome was confirmed as an $\mathrm{X}$ by banding.

We agree that Renpenning syndrome is associated with the fragile site at Xq27-28 and with macroorchidism, but not exclusively. Two other families were ascertained whose clinical symptoms and signs precluded them from being classified as Renpenning syndrome, yet they carried the fragile site Xq27-28.

We wish to thank all the consultants, particularly Dr Mary Vowles, who have given us permission to study their patients, Ms Liz Perkins for the psychological assessment, Dr J Insley for supervision, and Professor D G Harnden and Dr S Bundey for their helpful comments on the manuscript. We also thank the British Institute of Mental Handicap and the Birmingham Children's Hospital Centenary Research Fund for financial support.

\section{References}

1 Dunn HG, Renpenning H, Gerrard JW, Miller JR, Tabata T, Fedoroff S. Mental retardation as a sex-linked defect. Am J Ment Defic 1962; 67: 827-48.

2 Renpenning H, Gerrard JW, Zaleski WA, Tabata T. Familial sex-linked mental retardation. Can Med Ass $J$ 1962; 87: 954-6.

3 Martin JP, Bell J. A pedigree of mental defect showing sex linkage. J Neurol Psychiatr 1943; 6: 154-7.

4 Turner G, Turner B, Collins E. X-linked mental retardation without physical abnormality in Renpenning's syndrome. Dev Med Child Neurol 1971; 13: 71-8.

5 Lehrke RG. X-linked mental retardation and verbal disability. Birth Defects 1974; 10: 1-100.

6 McLaughlin JF, Kriegsmann E. Developmental dyspraxia in a family with X-linked mental retardation (Renpenning's syndrome). Dev Med Child Neurol 1980; 22: 84-92.
7 Turner G, Eastman C, Casey J, McLeay A, Procopis P, Turner B. X-linked mental retardation associated with macro-orchidism. J Med Genet 1975 ; 12 : 367-70.

8 Turner G, Tee R, Daniel A. Marker X chromosomes, mental retardation and macro-orchidism. $N$ Engl J Med $1978 ; 299$ : 1472 .

9 Lubs HA. A marker X chromosome. Am J Hum Genet $1969 ; 21: 231-44$.

10 Harvey J, Judge C, Weiner S. Familial X-linked mental retardation with an $\mathrm{X}$ chromosome abnormality. $J$ Med Genet 1977; 14: 46-50.

11 Sutherland GR. Heritable fragile sites on human chromosomes. II Distribution, phenotypic effects, and cytogenetics. Am J Hum Genet 1979 ; 31 : 136-48.

12 Sutherland GR. Heritable fragile sites on human chromosomes. I Factors affecting expression in lymphocyte culture. Am J Hum Genet 1979; 31 : 125-35.

13 Sutherland GR. Heritable fragile sites on human chromosomes. III Detection of fra (X) (q27) in males with $\mathrm{X}$-linked mental retardation and their female relatives. Hum Genet 1979; 53: 23-7.

14 Sutherland GR, Ashforth PLC. X-linked mental retardation with macro-orchidism and the fragile site at Xq27 or 28. Hum Genet 1979; 48: 117-20.

15 Jacobs PA, Mayer M, Rudale E, et al. More on marker $\mathrm{X}$ chromosomes, mental retardation and macro-orchidism. $N$ Engl J Med 1979; 300: 737-8.

16 Tanner JM. Growth at adolescence. Oxford: Blackwell, 1962.

17 Prader A. Testicular size: assessment and clinical importance. Triangle 1966; 7: 240-3.

18 Zachmann M, Prader A, Kind A, Hafliger HP, Budliger $H$. Testicular volume during adolescence. Cross-sectional and longitudinal studies. Helv Paediatr Acta 1974; 29: 61-72.

19 Seabright M. A rapid banding technique for human chromosomes. Lancet 1971 ; ii: 971-2.

20 Heath CW. Cytogenetic observations in vitamin B12 and folate deficiency. Blood 1966; 27: 800-15.

21 Lubs HA. Testicular size in Klinefelter's syndrome in men over 50. N Engl J Med 1962; 267: 326-31.

22 Howard-Peebles PN, Stoddard GR, Mims MG. Familial $\mathrm{X}$-linked mental retardation, verbal disability and marker X chromosomes. Am J Hum Genet 1979; 31 : 214-22.

${ }^{23}$ Penrose LS. A clinical and genetic study of 1280 cases of mental defect (the 'Colchester Survey'). London: Institute for Research into Mental and Multiple Handicap, 1938.

Requests for reprints to Dr T Webb, Department of Clinical Genetics, Infant Development Unit, Birmingham Maternity Hospital, Birmingham B15 2TG. 